\title{
Impacts of Forest Cover on Surface Runoff Quality in Small Catchments
}

\author{
Marek Trenčiansky, ${ }^{\mathrm{a}, *}$ Martina Šterbová, ${ }^{\mathrm{b}}$ Jozef Výbošt’ok, ${ }^{\mathrm{a}}$ and Martin Lieskovskýc \\ Forest cover influences not only the amount of surface runoff, but also its \\ quality. The concentrations of chemicals in surface runoff differ between \\ forest catchments and non-forest catchments (agricultural areas). The \\ authors investigated the chemical compositions of surface runoff in two \\ small neighboring catchments (forest, non-forest), by analyzing and \\ summarizing data over a period of 26 years from 1986 to 2012. During this \\ period, the stock and absorption area of forest stands increased, air quality \\ improved, the agricultural landscape was partly regenerated, and global \\ climate change became apparent. The authors observed differences in \\ surface runoff between forest- and non-forest catchments. However, these \\ differences were not mainly caused by the influence of the forest cover, \\ but by changes in agricultural land management. Since 2006, agricultural \\ land has been managed without the use of artificial fertilizers, which \\ reduced the contents of pollutants in surface runoff from the non-forest \\ catchment. The existence of the forest as such excludes or noticeably \\ eliminates the use of fertilizers and chemical substances that affect water \\ quality.
}

Keywords: Water quality; Forestry; Agriculture; Forest ecosystem services

Contact information: a: Department of Forest Economics and Management, Faculty of Forestry, Technical University in Zvolen T. G. Masaryka 24, 96053 Zvolen, Slovakia; b: National Forest Centre - Forest Research Institute Zvolen, T. G. Masaryka 2175/22, 96092 Zvolen, Slovakia, Department of Forest Economics and management, Faculty of Forestry, Technical University in Zvolen T. G. Masaryka 24, 960 53 Zvolen, Slovakia; c: Department of Forest Harvesting, Logistics and Ameliorations, Faculty of Forestry, Technical University in Zvolen, T. G. Masaryka 24, 96053 Zvolen, Slovakia;

*Corresponding author: trenciansky@tuzvo.sk

\section{INTRODUCTION}

On a global level, forests generate a multitude of environmental goods and services. Of these, water-related services were ranked among the crucial forest ecosystem services (ES) (Hamilton et al. 2008; Čaboun et al. 2010; Robinson and Cosandey 2011). The importance of forests to water quantity and quality as well as watershed management is not a new concept. Although, it is often understood as something detected in $20^{\text {th }}$ century, water and soil have been linked throughout all of human civilization (Diamond 2005). There is a need to understand the water balance operating in catchments, the processes controlling water movements, and the impacts of land-use change on water quantity and quality. The interactions between physical, chemical, and biological factors have become an increasingly dominant theme, and this has been boosted by global environmental issues, such as acid rain and climate change (Whitehead and Robinson 1993).

Land use and the composition of land cover (LULC) within a catchment play a key role in regulating stream water quality (Feller 2005; Carr and Neary 2008; Giri and Qiu 2016). Landscape elements have been identified as the most important parameters affecting water quality through their impacts on non-point source pollution resulting from complex 
run-off and landscape interactions (Gergel 2005; Snyder et al. 2005; Uuemaa et al. 2007; Moreno-Mateos et al. 2008; Carvalho-Santos et al. 2016). Considering surface runoff from catchment areas into water bodies as the main source of nutrients and pollutants (Tong and Chen 2002), the relationship between water quality and changes in land use has become increasingly important (Xiao et al. 2016). The conversion of native vegetation to agriculture and human settlements has resulted in the degradation of many ecosystem services and of biodiversity (Foley et al. 2005).

As Baillie and Neary (2015) state, forests can be considered as a major factor influencing catchment hydrology. Forest land use is generally associated with the protection of water resources from contamination (Abildtrup and Strange 2000; Willis 2002; Ernst et al. 2004), reducing the amounts of sediment, nutrients, and contaminants (Amatya et al. 2003; Robinson and Cosandey 2011) and maintaining good water quality (Aust et al. 2011). Neary et al. (2009) and Sukhdev et al. (2010) stress that the most sustainable and high-quality water sources originate in forest ecosystems, particularly in virgin forests. On the other hand, agriculture and urbanization are the main sources of nutrients and xenobiotics, which subsequently degrade water quality, while forestlands and wetlands act as sinks of non-point-source pollution (Bennett et al. 2001)

The physical, biological, and chemical characteristics of forest soils facilitate water filtration, contaminant removal, and nutrient (especially of nitrogen) recycling (Neary et al. 2009; Liu et al. 2012; Baillie and Neary 2015). Jussy et al. (2002) and RaulandRasmussen et al. (2011) observed low levels of nitrate and various pollutants (e.g., pesticides) under forest cover. Forest soils feature litter layers and high organic matter levels, both of which contribute to an abundant and diverse micro- and macro-fauna. Compared to agricultural lands and grasslands, root systems of forests are extensive, relatively deep and well-developed, thus efficiently extract soil moisture for tree growth; they also transpire more water than other vegetation types. Perennial plants and organic uptake matter in forest soils help to retain nutrients. Consequently, surface runoff is reduced in forest environments, and most rainfall moves to streams by subsurface flow pathways, where nutrient uptake and cycling as well as contaminant sorption processes are rapid (Neary et al. 2009).

Forests also prevent erosion and nitrogen runoff. McBroom et al. (2008) found that forest catchments retain most nitrogen inputs, even after timber harvesting. Afforestation affects floor drainage, and in most cases, forests can substantially reduce the need for drinking water treatment, thus decreasing water supply costs.

The importance of assessing the relationship between LULC and water quality is obvious (Brauman et al. 2007; Uuemaa et al. 2007). Many stakeholders are aware of this issue and recognize the role of forest systems in the supply of a number of non-market services, including the protection and prevention of water resources (Dudley and Stolton 2003). In this sense, the aim of this study is to analyse and evaluate the long-term impacts of forest systems on the surface runoff quality in two neighbouring catchments from 1986 to 2012. One of the catchments is covered with forest, while the other is mainly used for agricultural production. With this on mind, the following research questions were formulated:

- RQ1: Which qualitative parameters of water were affected by the forest?

- RQ2: Which qualitative parameters of water were affected by potential identified influences? 
The length of the analyzed period makes it possible to assess and identify whether the changes in the analyzed runoff parameter are influenced by the forest itself or whether the change in the parameter was caused by another effect. Potential identified impacts within the analyzed period include the greening of agriculture in non-forested catchment ( "greening" means support of farmers who adopt or maintain farming practices that help meet environmental and climate goals), improvement of air quality and manifestations of climate change.

\section{EXPERIMENTAL}

\section{Study Site}

The authors examined the chemical characteristics of surface runoff in two small, neighboring catchments in Central Slovakia in the Slovenské rudohorie. The first catchment $\left(0.94 \mathrm{~km}^{2}\right)$ had a forest cover area of $85 \%$ (green point in Fig. 1); the dominant tree species were spruce (Picea abies) and beech (Fagus sylvatica). Most trees were planted in 1986 and were 17 years old at the beginning of the experiment and 43 years old at the end of the experiment. Average annual water flow was $16 \mathrm{~L} . \mathrm{s}^{-1}$.

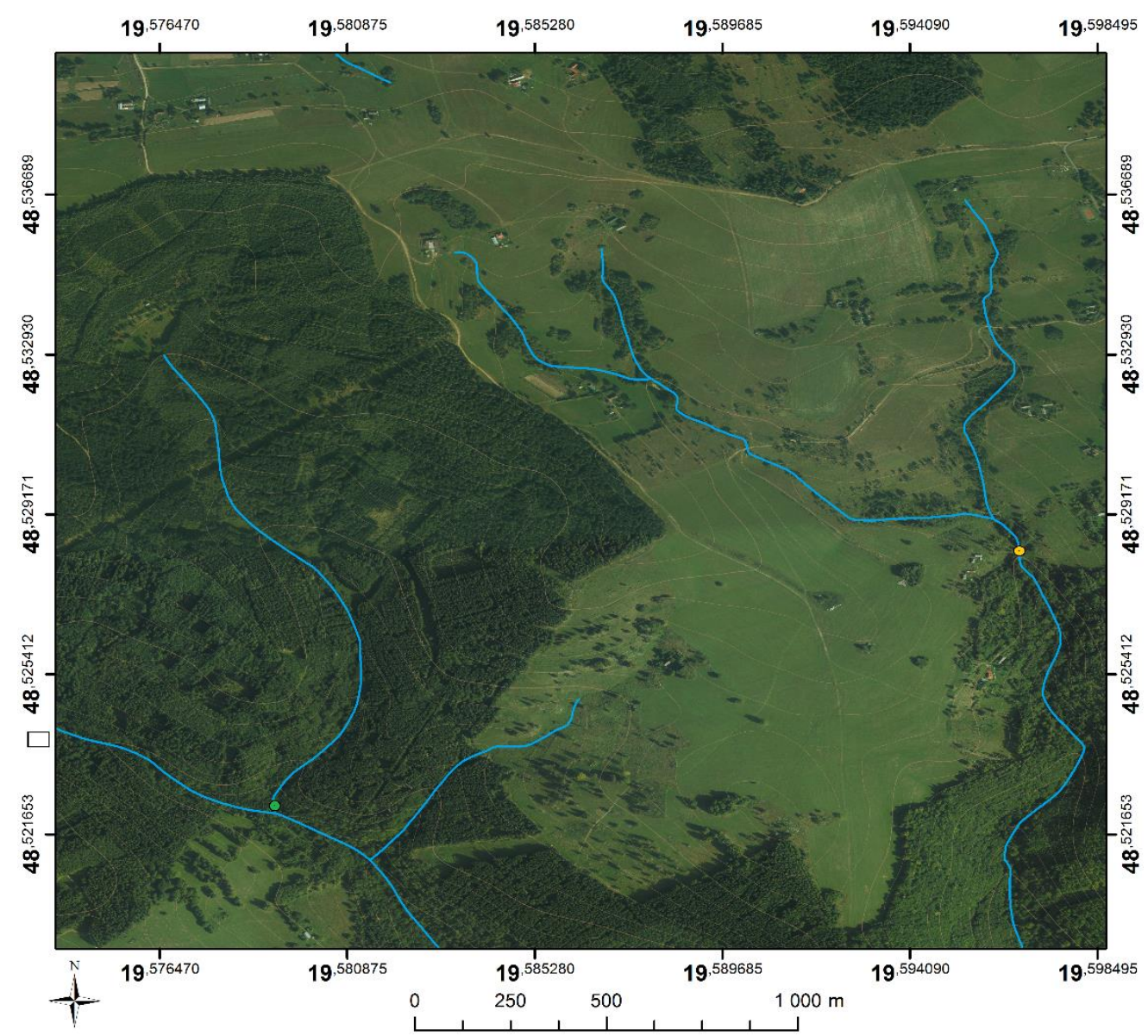

Fig. 1. Aerial photograph of the study site. The green point represents the sampling plot for the forest catchment and the orange point represents the sampling plot for the non-forest catchment. 
The second catchment $\left(1.44 \mathrm{~km}^{2}\right)$ was located outside the forest and consisted of meadow (70\%) and arable land (30\%) (orange point in Fig. 1). At the beginning of the experiment, this catchment was used for intensive animal and crop production, with the use of fertilizers and chemical preservatives. In the 1990s, there was a gradual decrease in agricultural production. The number of farmed animals decreased (sheep from 3000 to 1 800 , cattle from 3000 to 150), and the area of farmed land decreased markedly (1980 there was approx. 4000 ha, and in 2012 there was 1500 ha). Some unused arable land was turned into meadows, and some parts became overgrown with shrub species. Since 2006, it has been converted to an organic production unit, and synthetic fertilizers and chemical preservatives were banned. Average annual water flow was $31{\mathrm{~L} . \mathrm{s}^{-1}}^{-}$

Both catchments are located at an average elevation of $850 \mathrm{~m}$ above sea level; average annual rainfall is $920 \mathrm{~mm}$ and average annual temperature $5{ }^{\circ} \mathrm{C}$. The geological subsoil of both catchments consists of granodiorites and is homogeneous, enabling comparisons between the two catchments. The soil is unsaturated brown soil. Total humus levels reach 225 to $250 \mathrm{t} \mathrm{ha}^{-1}$; humus form is moder. Total nitrogen supply is 6.0 to $6.5 \mathrm{t}$ $\mathrm{ha}^{-1}$. Most parts of the catchments have a slope of up to $30 \%$, and both catchments are classified as areas with minimal human impact (Klinda et al. 2016).

The catchments have a different water flow due to their different size. After conversion to square kilometres, the water flow in the forested catchment would reach the value of $17 \mathrm{~L} . \mathrm{s}^{-1} \cdot \mathrm{km}^{-2}$, in the non-forest catchment $21.5 \mathrm{~L} \cdot \mathrm{s}^{-1} \cdot \mathrm{km}^{-2}$. Due to the equal exposure, slope, geological and soil conditions, we assume that the different recalculated average water flow is caused by different evapotranspiration.

\section{Sample Collection}

The water samples were collected in the following periods: 1986 to 1990,1992 to 1994, and 2009 to 2012. Samples were always taken once a month from the exact same place at approximately $1.5 \mathrm{~km}$ from the source of the streams. For the purposes of sampling, dams were built in both catchments in 1986. Samples were taken into sterilized containers - sample boxes according to the instructions of the laboratory from a depth of 5 to $10 \mathrm{~cm}$ below the surface of the stream. After sampling, the sample boxes were transported in the refrigerator to the laboratory. Water analyses in the first two periods were carried out by the Technical University in Zvolen, while in the third period, they were performed by Stredoslovenská vodárenská spoločnost' (Central Slovak Water Company). The following parameters were determined: nitrites, nitrates, chlorides, sulphates, phosphates (all in $\mathrm{mg}$ $\mathrm{L}^{-1}$ ), coliform bacteria (CFU $100 \mathrm{~mL}^{-1}$ ), and $\mathrm{pH}$. The numbers of samples taken in each year are shown in Table 1 . A total of 93 samples were analyzed for each catchment.

Table 1. Number of Samples Taken Each Year for Water Analysis

\begin{tabular}{|c|c|c|c|c|c|c|}
\hline Number of samples /Year & $\mathbf{1 9 8 6}$ & $\mathbf{1 9 8 7}$ & $\mathbf{1 9 8 8}$ & $\mathbf{1 9 8 9}$ & $\mathbf{1 9 9 0}$ & $\mathbf{1 9 9 2}$ \\
\hline Forest Catchment & 8 & 9 & 11 & 9 & 4 & 1 \\
\hline Non-forest Catchment & 8 & 9 & 11 & 9 & 4 & 1 \\
\hline Number of Samples /Year & $\mathbf{1 9 9 3}$ & $\mathbf{1 9 9 4}$ & $\mathbf{2 0 0 9}$ & $\mathbf{2 0 1 0}$ & $\mathbf{2 0 1 1}$ & $\mathbf{2 0 1 2}$ \\
\hline Forest Catchment & 9 & 2 & 7 & 9 & 12 & 12 \\
\hline Non-forest Catchment & 9 & 2 & 7 & 9 & 12 & 12 \\
\hline
\end{tabular}




\section{Statistical Analysis}

From the point of view of processing statistical analyses, the authors divided the analysed period into the first (1986-1994) and second (2009-2012) experimental period. All statistical analyses were conducted in accordance with Statistical methods in water resources (Helsel and Hirsch 1992). When assessing the trend of the development content of individual elements over time for forest and non-forest catchments, the authors used linear trend. Since Kolmogorov-Smirnov test showed that the data do not have a normal distribution (Table 2), the Mann-Whitney U test was used for the analysis of the differences between forest and non-forest catchments. Subsequently, the Mann-Kendall trend test was chosen for assessing the trend over time.

Table 2. Results of Kolmogorov-Smirnov Test

\begin{tabular}{|l|l|}
\hline Water parameters & p-value \\
\hline Nitrates & $0.000^{\star * *}$ \\
\hline Chlorides & $0.000^{* * *}$ \\
\hline Sulphate & $0.019^{*}$ \\
\hline $\mathrm{pH}$ & $0.000^{\star * *}$ \\
\hline Coliform bacteria & $0.000^{\star * *}$ \\
\hline Iron & $0.000^{\star * *}$ \\
\hline Nitrite & $0.000^{* * *}$ \\
\hline Phosphate & $0.000^{* * *}$ \\
\hline
\end{tabular}

For all statistical analyses the authors used R studio (version 1.3.1093, RStudio PBC, Boston, MA, USA).

\section{RESULTS}

The monitored characteristics can be divided into two groups: Group 1, where the difference between the analyzed characteristics in the forested and forest-free catchment areas was not significant, and Group 2, where the difference between the analyzed characteristics was statistically significant.

\section{Water Parameters Not Influenced by Forest Cover}

Group 1 contained the parameters for nitrates, phosphates, iron, and coliform bacteria, which did not differ between forest and non-forest catchments. In the long term, nitrite and phosphate contents were balanced in both catchments. The increased variability of both elements results from the uneven elution of nitrites and phosphates, depending on precipitation. The contents of iron and coliform bacteria showed a slightly increasing trend in both catchments. Iron reaches the surface runoff by transport with dissolved organic matter or from geological bedrock and soil. Faecal contamination results in higher levels of coliform bacteria.

There were no statistically significant differences between forest and non-forest areas. 


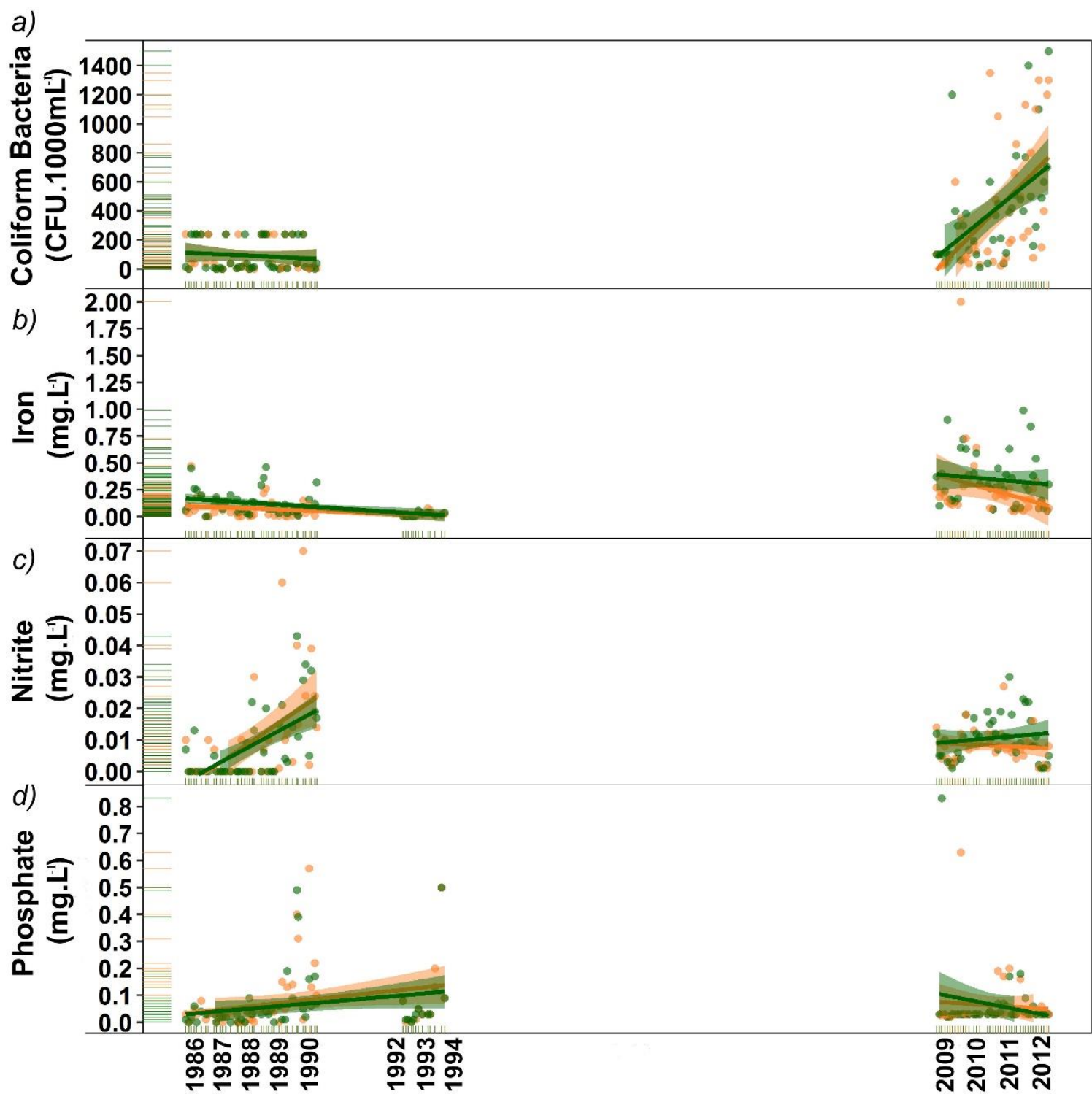

Fig. 2. Linear regression analysis for forest and non-forest areas - water parameters not influenced by forest cover. The contents of water parameters of the surface runoff (a) Coliform Bacteria, (b) Iron, (c) Nitrite, (d) Phosphate. Orange color represents the non-forest area and green color the forest area. Color shadow represents the 95\% confidence interval (CFU - Colony Forming Units)

Table 3. Influence of Forest Cover on Surface Runoff Quality - Water Parameters not Influenced by Forest Cover

\begin{tabular}{|l|l|}
\hline Water Parameters & p-value \\
\hline Coliform bacteria & 0.599 \\
\hline Iron & 0.051 \\
\hline Nitrite & 0.327 \\
\hline Phosphate & 0.914 \\
\hline
\end{tabular}

* $p$-values of Mann-Whitney U test 


\section{Water Parameters Influenced by Forest Cover}

Group 2 consisted of the parameters $\mathrm{pH}$, sulphate, nitrates, and chlorides, which were significantly impacted by forest cover. Water $\mathrm{pH}$ was lower in the forested area. The acidity of runoff water in both catchments was higher in the first analysed period (19861994). In the second period (2009 to 2012) in a forest catchment the water $\mathrm{pH}$ had a decreasing and in a non-forest catchment an increasing trend. The sulphate content increased significantly over time in the forest catchment and showed a slightly increasing trend in the non-forest catchment.

It was noteworthy that chlorides and nitrates decreased significantly over time in the non-forest catchment. In the second period (2009 to 2012), this difference between forest and non-forest catchments was not obvious. Since 2006, chemical preservatives and fertilizers have not been used in non-forest catchment. Based on the results from this study, forest cover had a significant effect on sulphate content and $\mathrm{pH}$, while changes in agricultural land management resulted in changes in nitrate and chloride levels.

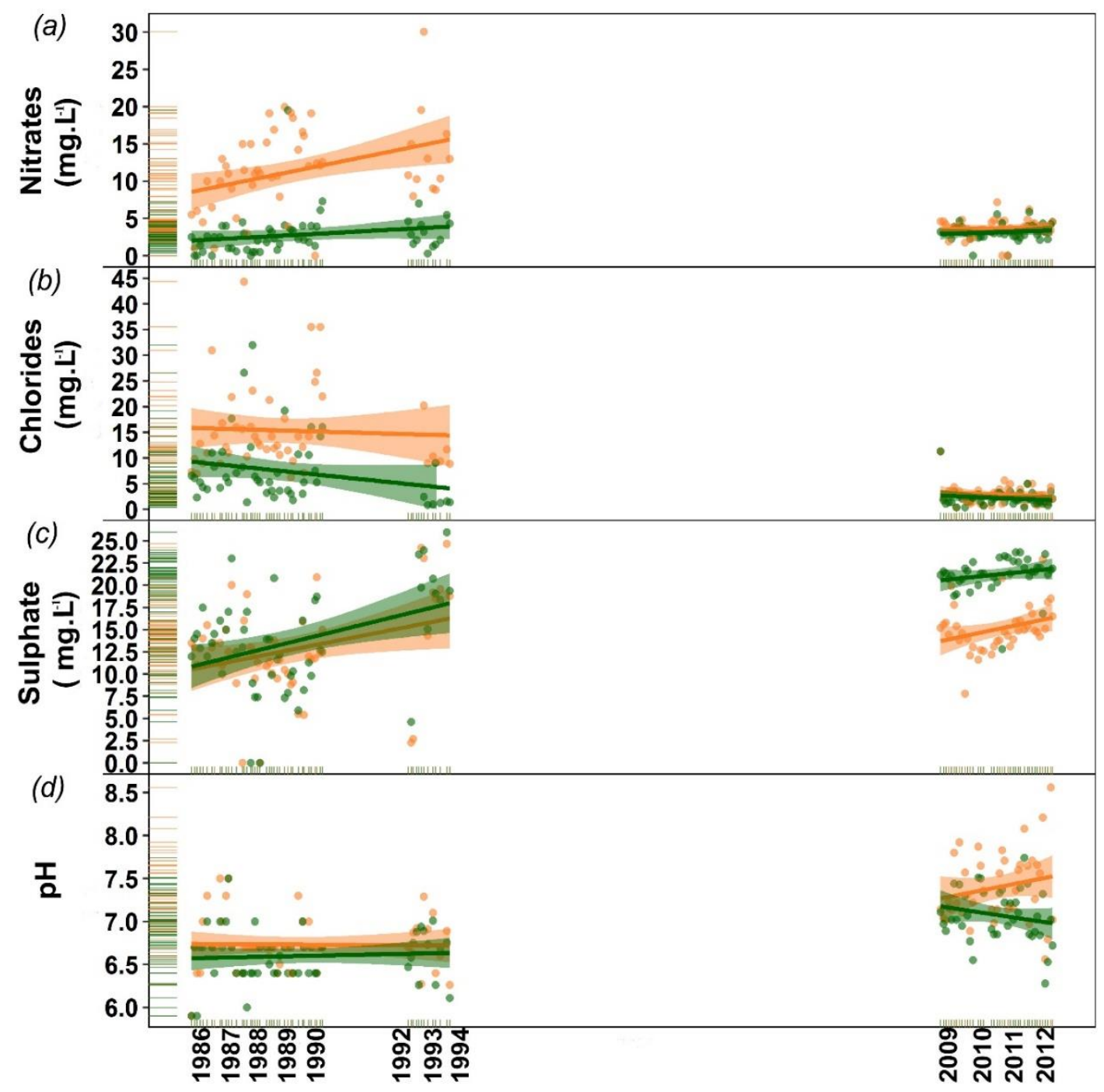

Fig. 3. Linear regression analysis for forest and non-forest areas - water parameters influenced by forest cover. The contents of water parameters of the surface runoff (a) Nitrates, (b) Chlorides (c) Sulphate, and (d) ph. Orange color represents the non-forest area and green color the forest area. Color shadow represents the $95 \%$ confidence interval 
Table 4. Influence of Forest Cover on Surface Runoff Quality - Water Parameters Influenced by Forest Cover

\begin{tabular}{|l|l|}
\hline Water Parameters & $\mathbf{p}$-value \\
\hline Nitrates & $0.000^{\star \star \star}$ \\
\hline Chlorides & $0.000^{\star \star \star}$ \\
\hline Sulphate & $0.000^{\star \star \star}$ \\
\hline $\mathrm{pH}$ & $0.007^{\star \star}$ \\
\hline
\end{tabular}

* p-values of Mann-Whitney U test

There were statistically significant differences between forest and non-forest areas.

Table 5. Analysis of Water Parameter Trends - Mann-Kendall Trend Test

\begin{tabular}{|c|c|c|c|c|}
\hline \multirow{2}{*}{ Water Parameters } & \multicolumn{2}{|c|}{ Forest } & \multicolumn{2}{|c|}{ No-forest } \\
\hline & p-value* & trend & p-value* & trend \\
\hline Nitrates & $0.001^{* *}$ & yes & $0.000^{\star * *}$ & yes \\
\hline Chlorides & $0.000^{* * *}$ & yes & $0.000^{\star * \star}$ & yes \\
\hline Sulphate & $0.000^{* * *}$ & yes & $0.000^{* * *}$ & yes \\
\hline $\mathrm{pH}$ & $0.000^{* * *}$ & yes & $0.000^{\star * *}$ & yes \\
\hline Coliform bacteria & $0.000^{* * *}$ & yes & $0.000^{\star \star \star}$ & yes \\
\hline Iron & $0.002^{* *}$ & yes & $0.000^{* * *}$ & yes \\
\hline Nitrite & $0.000^{\star \star *}$ & yes & $0.002^{\star *}$ & yes \\
\hline Phosphate & $0.011^{*}$ & yes & 0.094 & no \\
\hline
\end{tabular}

* $p$-values of Mann-Kendall Trend test

Drinking water quality was determined according to the threshold values of the selected indicators. Table 6 shows the average values of the parameters for each catchment and period; threshold values for drinking water were obtained from Decree no. 247/2017 (Ministry of Health of the SR 2017).

Table 6. Average and Threshold Values of Water Quality Parameters

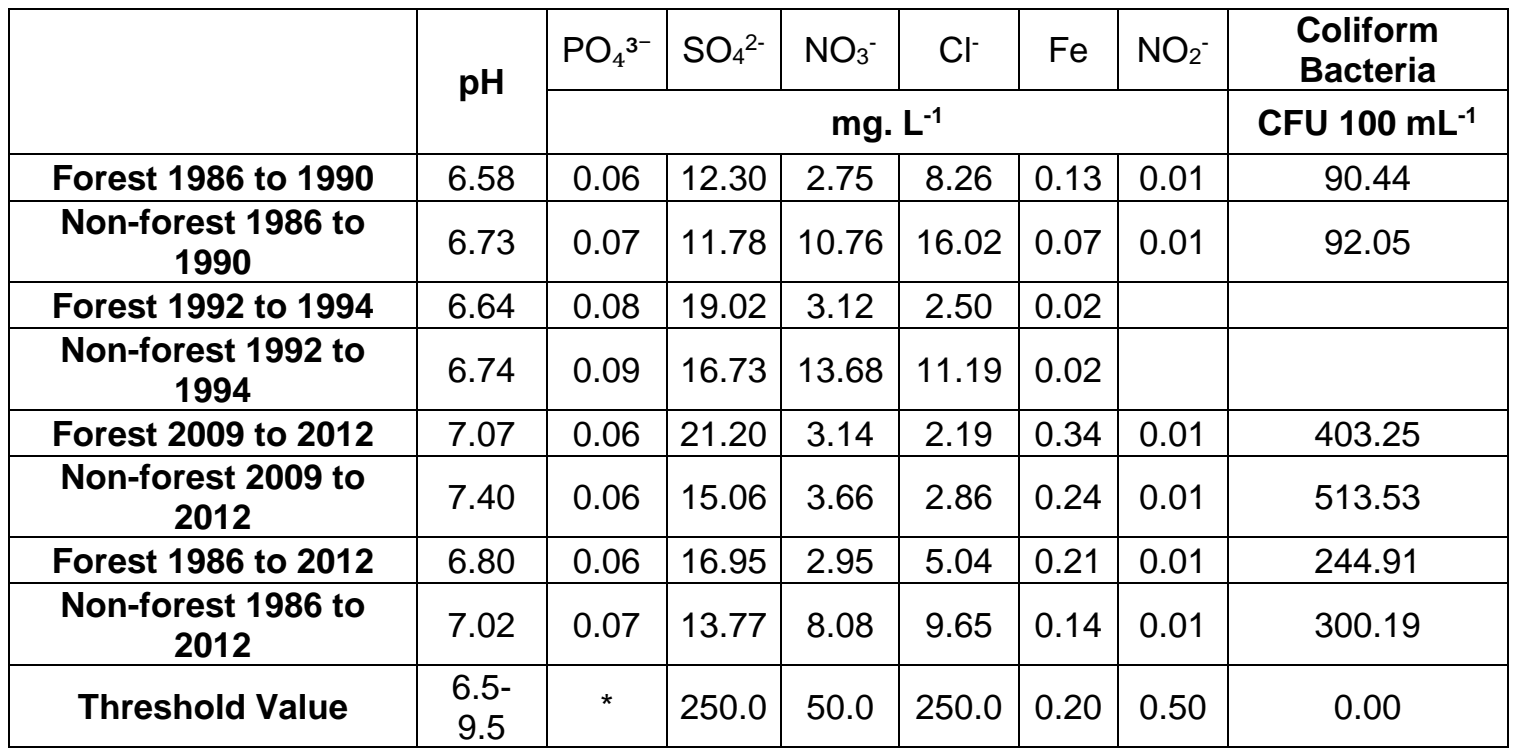

(CFU - Colony Forming Units) 
All of the experimental parameters studied, with the exception of iron levels and coliform bacteria, met the requirements for drinking water. Water from both catchments could be treated similarly.

\section{DISCUSSION}

Out of the eight measured water quality parameters, statistical significance between forested and non-forest catchments was confirmed for four parameters, namely $\mathrm{pH}$, sulphates, chlorides, and nitrates. For these parameters, it was necessary to determine whether the difference was caused by the influence of the forest cover or by potential identified factors (the greening of agriculture in non-forested catchment, improvement of air quality, and manifestations of climate change).

Based on the authors' results, forest cover significantly influenced two water quality parameters: sulphates content and water $\mathrm{pH}$. Acidity of run-off water from the forested catchment was higher than that from the non-forested catchment. According to previous studies, through fall and stemflow have significantly lower $\mathrm{pH}$ values than bulk precipitation (Xi et al. 2009; Xu et al. 2013). In the forest catchment, higher sulphate levels were measured in the run-off water than in the non-forest catchment. In the first experimental period (1986 to 1994), this difference was insignificant, while over time, it increased, and in the second experimental period (2009 to 2012) this difference was significant. This can be explained by the increasing absorption area of forest stands over time. The increase in sulphate concentration is associated with the absorption of sulphur oxides through forest stands, their transformation into sulphates, and the subsequent adsorption from the soil. In the region, horizontal rainfall is frequent, thus increasing this effect. This is also reflected in the increasing trend of the average sulphate concentration in the forest catchment (1986 to 1990: $12.3 \mathrm{mg} \mathrm{L}^{-1}$; 1992 to 1994: $19.0 \mathrm{mg} \mathrm{L}^{-1}$; and 2009 to 2012: $\left.21.20 \mathrm{mg} \mathrm{L}^{-1}\right)$. A slightly increasing trend was also observed in the non-forest catchment (1986 to 1990: $11.8 \mathrm{mg} \mathrm{L}^{-1} ; 2009$ to 2012: $16.7 \mathrm{mg} \mathrm{L}^{-1}$ ). This increase is related to the gradual reduction of agricultural production, in particular by changing part of arable land to meadows and pastures, thereby increasing the absorption area of the shore forest in the non-forest catchment. The lower $\mathrm{pH}$ in the forest catchment can be similarly explained by the combing effect of sulphur oxides through forest stands, with subsequent acidification of the run-off water. The long-term effect of the acidic disposition caused by industrial emissions, especially in the 1980s, resulted in a "limit load on land" (Stachera and Lalkovič 2000). This load increased the acidity of the run-off water during the first period (1986 to 1994). In the 1990s, industrial production was reduced, which significantly reduced sulphur oxides in the atmosphere. In the 1990s, annual $\mathrm{SO}_{2}$ emissions in the Slovak Republic exceeded 500,000 tons. In the 1990s, a gradual decline began, and in the second period (2009 to 2012), $\mathrm{SO}_{2}$ emissions were at the level of 50,000 tons per year, representing a 10-fold decrease (Ministry of Environment of the SR 1999; Statistical Office of the SR 2019). This resulted in a slight increase in the $\mathrm{pH}$ value of the run-off water in both catchments (forest catchment: from 6.6 to 7.1; non-forest catchment: from 6.7 to 7.4).

In this study, nitrate and chloride levels confirmed the statistical significance between forested and non-forested areas in the first experimental period (1986 to 1994). This difference can be attributed to the changes in the management of agricultural production in the non-forest catchment. In the 1980s and 1990s, the nitrate content in the non-forest catchment was, on average, four times higher, while the chloride levels were 
five times higher than those in the forest catchment. The concentrations of nitrates and chlorides in the non-forest area were significantly influenced by applying ecological knowledge and practices, such as the exclusion of fertilizers and chemical products since 2006 and the conversion of arable land to meadows and pastures. In the second experimental period (2009 to 2015) the difference was insignificant between forested and non-forested areas. Fiquepron et al. (2013) state that meadows and pastures can offer favourable conditions in relation to denitrification and water quality. Effective filters also include hedges and other linear forested areas. The intensification of agricultural production, combined with the use of fertilizers and pesticides, has a key impact on water quality (Stoate et al. 2001; Allan 2004; Hering et al. 2006; Mahler and Barber 2017). In this study, in the 1980s, an agricultural land manager used an average of 1,000 tons of fertilizer per year, which is almost 0.5 tons per ha. The proportion of nitrogen in fertilizers was almost $100 \mathrm{~kg} \mathrm{ha}^{-1}$. At the same time, chlorine-containing preservatives were used to protect agricultural crops (Aminex, Gramaxone, Retacel, Agritox). The significant influence of agrarian landscapes on nitrogen has been confirmed e.g., in China (Chen et al. 2016), Brazil (de Oliveira et al. 2016), and Spain (Álvarez-Cabria et al. 2016). Recycling, especially of nitrogen, is important in forest ecosystems. Nitrate levels are therefore low under forest cover (Raulund-Rasmussen et al. 2011). Surface runoff from agricultural lands is the main cause of water pollution (Hascic and $\mathrm{Wu} 2006$ ), and nitrification is greater in an agricultural environment.

For other elements, e.g., nitrites and phosphates, the increased values in the run-off water of the non-forest catchment were not a result of fertilizer use.

Global climate change increases the rate of atmospheric precipitation (Pecho et al. 2018). In both catchments, an increase in the elution of nitrogen oxides and phosphates in run-off water in relation to such change has not been confirmed. However, this result is influenced by factors, such as slope and relief, land management, among others.

The increased content of coliform bacteria in the non-forest catchment, most likely as a result of grazing livestock (sheep, cattle) and manure fertilization ( $20 \mathrm{t} \mathrm{ha}^{-1}$ year $\left.^{-1}\right)$ in parts of the territory (approximately 30\%) was not confirmed. Regarding iron levels, forest cover had no significant impact; iron reaches the surface runoff by transport with dissolved organic matter or from geological bedrock and soil.

All water parameters in both catchments, with the exception of coliform bacteria and iron concentration, met the drinking water requirements. Based on the findings for $\mathrm{pH}$ and sulphate content, the positive effect of forest cover on air purification could be confirmed. However, the present results suggest that the ecosystem services reported in some earlier works might have been partially over-estimated in terms of contributions of forest cover itself on water quality. When assessing the impact of the forest on water quality, it is necessary to take into account other impacts that operate in the compared area. It is mainly a way of agriculture management. The impact of the greening of agricultural production areas on water quality was more significant than that of the forest cover. The existence of forest in a catchment means the significant elimination of the use of artificial fertilizers or chemical preparations; in the study sites, fertilizers and chemical preservatives were not used in the analysed forest catchment. Forest management in generally less intensive than the management of agricultural areas, with less frequent interventions. Forest management is not neutral in terms of water quality, but many factors tend to attenuate harmful effects, particularly the fact that human interventions are less frequent in this sector than in agriculture (Fiquepron et al. 2013). There have been examples of land- 
use change from agriculture to forestry to promote better water quality (Hunsaker and Levine 1995; Hiscock et al. 2007).

Forests moderate climatic extremes, influencing the quantity, timing, thermal regime, and water quality characteristics of stream water (Neary et al. 2009). Forested catchments are generally assumed to provide higher quality water in contrast to agricultural and urban catchments. However, this should be tested in various ecological contexts and through the study of multiple variables describing water quality.

\section{CONCLUSIONS}

1. The results from long-term study in run-off water from forested and non-forest catchments indicated that half of the analyzed water quality parameters confirmed the differences between the catchments. The forest itself affects the amount of sulphates and the $\mathrm{pH}$ of the surface runoff. Significant differences in other water quality parameters (nitrates, chlorides) indicate a change in agricultural management.

2. The growing trend of sulphates and decreasing $\mathrm{pH}$ in the surface runoff in a forested catchment indicates the capture of sulphur oxides by the forest their transformation into sulphates and the subsequent adsorption from the soil. This effect increases with increasing forest stock, respectively absorbed area of the forest stands. The other parameters of water quality were significantly affected by changes in agricultural land management, causing decreases in nitrate and chloride levels.

3. A significant reduction in nitrates and chlorides in the second experimental period suggests that greening of agricultural production areas affected the quality of surface runoff more strongly than the presence of a forest cover, most likely because of the reduction in fertilizer use. The existence of the forest as such excludes or significantly eliminates the use of fertilizers and chemical substances that affect water quality.

4. The higher water $\mathrm{pH}$ in both catchments in the second experimental period reflects the reduction of air pollution by sulphur oxides.

5. Regarding the parameter's phosphates, nitrites, iron, and coliform bacteria contents, there was no variance between forested and forest-free areas. Phosphates and nitrites do not appear in increased share in both catchments, which indicates their fixation in the soil. The increased iron content is caused by its transport with dissolved organic matter or from the geological subsoil and soil. Coliform bacteria contents show significant variability and is mainly related to the use of organic fertilizers and the grazing of livestock in non-forest catchment. In a forested catchment the variability is caused by the decomposition of organic matter.

6. Run-off water from agricultural catchments with the use of artificial fertilizers and chemical preparations contains an increased content of nitrates and chlorides. After the greening of agriculture production, the water quality in both catchments is comparable. Water from both catchments met the requirements for drinking water (with the exception of iron levels and coliforms).

7. In both catchments, an increase in the elution of nitrogen oxides and phosphates in runoff water in relation to increases the rate of atmospheric precipitation has not been confirmed. The added value of the study is the 26-year length of the analyzed period. 
Based on changes in trends in water quality parameters, the potential impact of forest on runoff water quality was assessed. At the same time, possible causes of changes in the quality of runoff water in forested and non-forest catchments were identified. Further research will need to analyze, quantify, and evaluate these changes in more detail.

\section{ACKNOWLEDGMENTS}

The authors would like to thank the Scientific Grand Agency of the Ministry of Education, Science, Research and Sport of the Slovak Republic, and the Slovak Academy of Science. This paper was elaborated within the framework of Grant project "VEGA 1/0665/20 InnoWaFor: Innovation potential of payments for ecosystem services - Water and Forests". The Slovak Research and Development Agency supported the study under research projects "APVV-18-0347 Climate change and natural hazards impacts: adaptive capacity, and vulnerability of Western Carpatians forest ecosystems", "APVV-19-0612 Modelling the detrimental natural hazards occurrence risk impact on the economic complex forestry - wood processing under conditions of the ongoing climate change" and "APVV15-0715 Implementation and evaluation analysis of forest policy instruments".

\section{REFERENCES CITED}

Abildtrup, J., and Strange, N. (2000). "The option value of non-contaminated forest watersheds," Forest Policy and Economics 1(2), 115-125. DOI: 10.1016/S13899341(99)00005-2

Allan, J. D. (2004). "Landscapes and riverscapes: The influence of land use on stream ecosystems," Annual Review of Ecology Evolution and Systematics 35, 257-284. DOI: 10.1146/annurev.ecolsys.35.120202.110122

Álvarez-Cabria, M., Barquín, J., and Peñas, F. J. (2016). "Modelling the spatial and seasonal variability of water quality for entire river networks: Relationships with natural and anthropogenic factors," Science of The Total Environment 545, 152-162. DOI: $10.1016 /$ j.scitotenv.2015.12.109

Amatya, D. M., Skaggs, R. W., Gilliam, J. W., and Hughes, J. H. (2003). "Effects of orifice-weir outlet on hydrology and water quality of a drained forested watershed," Southern Journal of Applied Forestry 27(2), 130-142. DOI: 10.1093/sjaf/27.2.130

Baillie, B. R., and Neary, D. G. (2015). "Water quality in New Zealand's planted forests: A review," New Zealand Journal of Forestry Science 45(1), article no. 7. DOI: 10.1186/s40490-015-0040-0

Bennett, E. M., Carpenter, S. R., and Caraco, N. F. (2001). "Human impact on erodable phosphorus and eutrophication: A global perspective: Increasing accumulation of phosphorus in soil threatens rivers, lakes, and coastal oceans with eutrophication," BioScience 51(3), 227-234. DOI: 10.1641/00063568(2001)051[0227:HIOEPA]2.0.CO;2

Brauman, K. A., Daily, G. C., Duarte, T. K., and Mooney, H. A. (2007). "The nature and value of ecosystem services: An overview highlighting hydrologic services," Annual Review of Environment and Resources 32, 67-98. DOI: 10.1146/annurev.energy.32.031306.102758 
Čaboun, V., Tutka, J., Moravčík, M., Kovalčík, M., Sarvašová, Z., Schwarz, M., and Zemko, M. (2010). Uplatňovanie funkcii lesa v krajine [Application of Forest Functions in the Landscape], Národné Lesnícke Centrum vo Zvolene, Zvolen, Slovakia.

Carr, G. M., and Neary, J. P. (2008). Water Quality for Ecosystem and Human Health, UNEP/Earthprint, Burlington, Ontario, Canada.

Carvalho-Santos, C., Nunes, J. P., Monteiro, A. T., Hein, L., and Honrado, J. P. (2016). "Assessing the effects of land cover and future climate conditions on the provision of hydrological services in a medium-sized watershed of Portugal," Hydrological Processes 30(5), 720-738. DOI: 10.1002/hyp.10621

Chen, Q., Mei, K., Dahlgren, R. A., Wang, T., Gong, J., and Zhang, M. (2016). "Impacts of land use and population density on seasonal surface water quality using a modified geographically weighted regression," Science of The Total Environment 572, 450466. DOI: $10.1016 /$ j.scitotenv.2016.08.052

Diamond, J. (2005). Collapse - How Societies Choose to Fail or Succeed, Viking Press, New York, NY, USA.

Dudley, N., and Stolton, S. (2003). Running Pure: The Importance of Forest Protected Areas to Drinking Water, World Bank/WWF Alliance for Forest Conservation and Sustainable Use, Glad, Switzerland.

Ernst, C., Gullick, R., and Nixon, K. (2004). "Conserving forests to protect water," Opflow 30(5), 1-7. DOI: 10.1002/j.1551-8701.2004.tb01752.x

Feller, M. C. (2005). "Forest harvesting and streamwater inorganic chemistry in western north America: A review 1," JAWRA Journal of the American Water Resources Association 41(4), 785-811. DOI: 10.1111/j.1752-1688.2005.tb04464.x

Fiquepron, J., Garcia, S., and Stenger, A. (2013). "Land use impact on water quality: Valuing forest services in terms of the water supply sector," Journal of Environmental Management 126, 113-121. DOI: 10.1016/j.jenvman.2013.04.002

Foley, J. A., DeFries, R., Asner, G. P., Barford, C., Bonan, G., Carpenter, S. R., Chapin, F. S., Coe, M. T., Daily, G. C., and Gibbs, H. K. (2005). "Global consequences of land use," Science 309(5734), 570-574. DOI: 10.1126/science.1111772

Gergel, S. E. (2005). "Spatial and non-spatial factors: When do they affect landscape indicators of watershed loading?," Landscape Ecology 20(2), 177-189. DOI: 10.1007/s10980-004-2263-y

Giri, S., and Qiu, Z. (2016). "Understanding the relationship of land uses and water quality in Twenty First Century: A review," Journal of Environmental Management 173, 41-48. DOI: 10.1016/j.jenvman.2016.02.029

Hamilton, L. S., Dudley, N., Greminger, G., Hassan, N., Lamb, D., Stolton, S., and Tognetti, S. (2008). Forests and Water: A Thematic Study Prepared in the Framework of the Global Forests Resources Assessment 2005, Food and Agriculture Organization, Rome, Italy.

Hascic, I., and Wu, J. (2006). "Land use and watershed health in the United States," Land Economics 82(2), 214-239. DOI: 10.3368/le.82.2.214

Helsel, D. R., and Hirsch, R. M. (1992). Statistical Methods in Water Resources, Vol. 49, Elsevier. 
Hering, D., Johnson, R. K., Kramm, S., Schmutz, S., Szoszkiewicz, K., and Verdonschot, P. F. M. (2006). "Assessment of European streams with diatoms, macrophytes, macroinvertebrates and fish: A comparative metric-based analysis of organism response to stress," Freshwater Biology 51(9), 1757-1785. DOI: 10.1111/j.13652427.2006.01610.x

Hiscock, K., Lovett, A., Saich, A., Dockerty, T., Johnson, P., Sandhu, C., Sünnenberg, G., Appleton, K., Harris, B., and Greaves, J. (2007). "Modelling land-use scenarios to reduce groundwater nitrate pollution: the European Water4All project," Quarterly Journal of Engineering Geology and Hydrogeology 40(4), 417-434. DOI: 10.1144/1470-9236/07-054

Hunsaker, C. T., and Levine, D. A. (1995). "Hierarchical approaches to the study of water quality in rivers," BioScience 45(3), 193-203. DOI: 10.2307/1312558

Jussy, J.-H., Koerner, W., Dambrine, É., Dupouey, J.-L., and Benoît, M. (2002). "Influence of former agricultural land use on net nitrate production in forest soils," European Journal of Soil Science 53(3), 367-374. DOI: 10.1046/j.13652389.2002.00468.x

Klinda, J., Mičík, T., Némethová, M., and Slámková, M. (2016). Environemntálna Regionalizácia Slovenskej Republiky 2016 [Environmental Regionalisation of the Slovak Republic 2016], Ministry of Environment of the Slovak Republic and Slovak Environment Agency, Bratislava, Slovakia.

Liu, W., Zhang, Q., and Liu, G. (2012). "Influences of watershed landscape composition and configuration on lake-water quality in the Yangtze River basin of China," Hydrological Processes 26(4), 570-578. DOI: 10.1002/hyp.8157

Mahler, R. L., and Barber, M. E. (2017). "Using benthic macro invertebrates to assess water quality in 15 watersheds in the Pacific Northwest, USA," International Journal of Sustainable Development and Planning 12(1), 51-60. DOI: 10.2495/SDP-V12-N1$51-60$

McBroom, M. W., Beasley, R. S., Chang, M., and Ice, G. G. (2008). "Storm runoff and sediment losses from forest clearcutting and stand re-establishment with best management practices in East Texas, USA," Hydrological Processes: An International Journal 22(10), 1509-1522. DOI: 10.1002/hyp.6703

Ministry of Environment of the SR (1999). State of the Environment Report of the Slovak Republic 1999, Bratislava, Slovakia.

Ministry of Health of the SR (2017). Decree of the Ministry of Health of the Slovak Republic No. 247/2017 Collection of Laws, Dated 9 October 2017, Laying Down Details of Drinking Water Quality, Drinking Water Quality Control, Monitoring and Risk Management of Drinking Water Supply, Ministry of Health of the SR, Bratislava, Slovakia.

Moreno-Mateos, D., Mander, Ü., Comín, F. A., Pedrocchi, C., and Uuemaa, E. (2008). "Relationships between landscape pattern, wetland characteristics, and water quality in agricultural catchments," Journal of Environmental Quality 37(6), 2170-2180. DOI: $10.2134 /$ jeq2007.0591

Neary, D. G., Ice, G. G., and Jackson, C. R. (2009). "Linkages between forest soils and water quality and quantity," Forest Ecology and Management 258(10), 2269-2281. DOI: 10.1016/j.foreco.2009.05.027 
de Oliveira, L. M., Maillard, P., and de Andrade Pinto, É. J. (2016). "Modeling the effect of land use/land cover on nitrogen, phosphorous and dissolved oxygen loads in the Velhas River using the concept of exclusive contribution area," Environmental Monitoring and Assessment 188(6), Article Number 333. DOI: 10.1007/s10661-0165323-2

Pecho, J., Markovič, L., Faško, P., and Madara, M. (2018). Výdatnost’ Atmosférických Zrážok na Slovensku sa Zvyšuje [The Yield of Atmospheric Precipitation in Slovakia is Increasing], Slovak Hydrometeorological Institute Bratislava, (http://www.shmu.sk/sk/?page=2049\&id=932), Accessed 30 Oct 2020.

Raulund-Rasmussen, K., Hansen, K., Katzensteiner, K., Loustau, D., de Jong, J., Gundersen, P., Humphrey, J. W., Ravn, H. P., and Klimo, E. (2011). Synthesis Report on Impact of Forest Management on Environmental Services (EFI Technical Report 56), EFI, Joensuu, Finland.

Robinson, M., and Cosandey, C. (2011). "Water resources depend on vegetation cover and land use," in: Water for Forests and People in the Mediterranean Region, Y. Birot, Y., C. Gracia, M. Palahi, (eds.), EFI, Joensuu, Finland, pp. 59-63.

Snyder, M. N., Goetz, S. J., and Wright, R. K. (2005). "Stream health rankings predicted by satellite derived land cover metrics," JAWRA Journal of the American Water Resources Association 41(3), 659-677. DOI: 10.1111/j.1752-1688.2005.tb03762.x

Stachera, J., and Lalkovič, M. (2000). "Vplyv lesnatosti povodia na chemizmus odtekajúcej vody [Influence of forested catchment areas on runoff water chemistry]," Lesnicky časopis-Forestry Journal 46(2), 187-201.

Statistical Office of the SR (2019). Environment of the SR (Selected Indicators in $2014-$ 2018), Statistical Office of the SR, Bratislava, Slovakia.

Stoate, C., Boatman, N. D., Borralho, R. J., Carvalho, C. R., De Snoo, G. R., and Eden, P. (2001). "Ecological impacts of arable intensification in Europe," Journal of Environmental Management 63(4), 337-365. DOI: 10.1006/jema.2001.0473

Sukhdev, P., Wittmer, H., Schröter-Schlaack, C., Nesshöver, C., Bishop, J., Brink, P., Gundimeda, H., Kumar, P., and Simmons, B. (2010). The Economics of Ecosystems and Biodiversity: Mainstreaming the Economics of Nature: A Synthesis of the Approach, Conclusions and Recommendations of TEEB, UNEP, Ginebra (Suiza), Switzerland.

Tong, S. T. Y., and Chen, W. (2002). "Modeling the relationship between land use and surface water quality," Journal of Environmental Management 66(4), 377-393. DOI: 10.1006/jema.2002.0593

Uuemaa, E., Roosaare, J., and Mander, Ü. (2007). "Landscape metrics as indicators of river water quality at catchment scale," Hydrology Research 38(2), 125-138. DOI: 10.2166/nh.2007.002

Whitehead, P. G., and Robinson, M. (1993). "Experimental basin studies-An international and historical perspective of forest impacts," Journal of Hydrology 145(3-4), 217-230. DOI: 10.1016/0022-1694(93)90055-E

Willis, K. G. (2002). "Benefits and costs of forests to water supply and water quality," Social and Environmental Benefits of Forestry Phase 2 (Report to Forestry Commision), Centre for Research in Environmental Appraisal \& Management University of Newcastle, Newcastle, UK. 
Xi, X. J., Yan, Q. L., Yu, L. Z., Zhu, J. J., Zhang, C. H., Zhang, J. X., and Liu, C. X. (2009). "Physical and chemical properties of throughfall in main forest types of secondary forest ecosystem in montane regions of eastern Liaoning Province, China," Ying Yong Sheng Tai Xue Bao (The Journal of Applied Ecology) 20(9), 2097-2104. DOI: $10.5846 /$ stxb201203280430

Xiao, R., Wang, G., Zhang, Q., and Zhang, Z. (2016). "Multi-scale analysis of relationship between landscape pattern and urban river water quality in different seasons," Scientific Reports 6(1), 1-10. DOI: 10.1038/srep25250

Xu, T. L., Zhu, J. J., Yu, L. Z., Wang, R. Z., and Zhang, J. X. (2013). "Physical and chemical properties of stemflow in different forest types of a secondary forest ecosystem in montane regions of eastern Liaoning Province, China," Acta Ecol Sin 33, 3415-3424. DOI: 10.5846/stxb201203280430

Article submitted: December 26, 2020; Peer review completed: April 24, 2021; Revised version received and accepted: August 12, 2021; Published: October 6, 2021.

DOI: 10.15376/biores.16.4.7830-7845 